mediastudies.press • Social Media \& the Self: An Open Reader

\title{
Idols of Promotion: The Triumph of Self-Branding in an Age of Precarity
}

Brooke Erin Duffy ${ }^{1}$, Jefferson Pooley ${ }^{2}$

${ }^{1}$ Cornell University, ${ }^{2}$ Muhlenberg College

Published on: Mar 30, 2019

License: Creative Commons Attribution 4.0 International License (C-BY 4.0). 


\section{Abstract}

By analyzing the "mass idols" (Lowenthal, 1944) of contemporary media culture, this study contributes to our understanding of popular communication, branding, and social media self-presentation. Leo Lowenthal, in his well-known analysis of popular magazine biographies, identified a marked shift in mass-mediated exemplars of success: from self-made industrialists and politicians ("Idols of Production") to screen stars and athletes ("Idols of Consumption"). Adapting his approach, we draw upon a qualitative analysis of magazine biographies (People and Time, $\mathrm{n}=127$ ) and social media bios (Instagram and Twitter, $\mathrm{n}=200)$, supplemented by an inventory of television talk show guests $(\mathrm{n}=462)$. Today's idols, we show, blend Lowenthal's predecessor types: They hail from the sphere of consumption, but get described - and describe themselves - in production terms. We term these new figures "Idols of Promotion" and contend that their stories of self-made success - the celebrations of promotional pluck - are parables for making it in a precarious employment economy.

Keywords: self-branding; social media; celebrity; labor; consumption; media content

ACCORDING TO A study that garnered extensive media coverage, young people now rank "YouTuber" among their top career choices, with aspirations of social media stardom displacing long-venerated professions like physician, lawyer, veterinarian, and teacher (Weiss, 2018). Indeed, YouTube stars, Instagram influencers, and other social media personalities occupy a prominent place in the popular imagination - whether held up as digitally enabled career exemplars or denigrated as product shills. Against this backdrop, academic inquiries into content creators and the wider culture of social media fame have proliferated in recent years (e.g., Abidin, 2018; Cunningham \& Craig, 2017; Duffy, 2017; Khamis et al., 2017; Marwick, 2013). Much of this work seems to suggest that there is something distinctive about visibility in the age of social media, Hearn and Schoenhoff (2015) call for a contextualization of new modes of renown, noting the dearth of studies that "historicize these developments, or...situate them within broader political economic transformations in the nature of work and value" (p. 195).

This study, then, locates contemporary valorizations of celebrity on a longer cultural timeline, building on Frankfurt School sociologist Leo Lowenthal's mid-century account. In 1944, Lowenthal published a comparative content analysis of "biographies" - short life histories of prominent figures-published in two popular U.S. magazines, Collier's and The Saturday Evening Post, between 1901 and 1941. He generated a mix of quantitative and qualitative data, from which he drew a sharp contrast between the turn-of-the-century biographies and those published forty years later. While profiles of politicians and business icons dominated the earlier period, Hollywood stars and athletes were far more 
prevalent by 1941. Clark Gable, in effect, was swapped in for J. P. Morgan. Lowenthal dubbed the industry titans and politicians "Idols of Production"; the entertainers feted later were, by comparison, "Idols of Consumption." Crucially, he treated the heroes as expressions of successive economic systems. The production idols of the past reflected the industrial economy of the late 19th century. Their biographies celebrated individualist, hard-won success in the country's "productive life," and portrayed these lives as models for emulation (pp. 512-513). By the 1940s, the economy's growing dependence on middle-class consumption was embodied by the idols of "leisure time" (p. 516). Small wonder that the culture's hero-selection had shifted to "headlines of the movies, the ball parks, and the night clubs" (p. 517).

The "mass idols" study is considered a classic - a frequently lauded (and sometimes criticized) touchstone of media research. Lowenthal's blend of content-analytic counting and fine-grained interpretation supplied something of an early model for mixed-methods investigation. But the study's bold linkage of renown to socio-economic change - the claim that an era's heroes reflect and reinforce the prevailing economic regime - is Lowenthal's signal contribution. The "mass idols" project was an implicit challenge to a then-nascent field: Attend to the social and economic conditions that inform shifts in the mass media landscape. The challenge, like the study itself, reflected Lowenthal's commitments to the European sociology-of-knowledge tradition. If "knowledge" is granted its full due, then surely idols and their magazine biographies cannot be detached from their underpinnings in the cultural economy. In the decades since Lowenthal's study, communication research, at least in the U.S., lost some of its sociological imagination (Pooley \& Katz, 2008). So the challenge stands, but the study itself is frozen in mid-century=: What would an analysis, sensitive to Lowenthal's original but set in current relief, look like? And how might such an analysis help to explain the careerist fetishization of YouTubers, Instagrammers, and the like?

The present study, by updating Lowenthal's 1940s analysis, explores the interrelationships between three contemporary developments: a flattened celebrity culture, a precarious labor market, and the heightened injunction to brand oneself online. We contend that twenty-first century celebrity is, in the classic sense of the word, a medium-one that helps communicate economic circumstances to mediated publics. The partial collapse of social distance between the famous and their fanspropelled in part by the interactive social media platforms they jointly occupy-quickens this work of mediation. Celebrities, by engaging in an analogous struggle to stand out, model practical skills of impression management for their audiences. It is in this respect that our study responds to Gill and Kanai's (2018) recent call for renewed intellectual attention to the role of mediated communication in producing affective subjectivities (p. 319).

Given the changed media landscape, we employed an adapted research design that included a qualitative analysis of popular magazine biographies and social media bios, supplemented by an 
inventory of television talk show guests. Weaving the data together, we identify three key tropes of mediated hero worship: (1) a promise a meritocracy; (2) a spirit of cross-platform self-enterprise; and (3) an endorsement of authentic self-expression. We conclude that 21st-century idols blend Lowenthal's predecessor types in telling ways. Like the "Idols of Consumption," today's heroes represent the leisure industries of media and sport. But they also share the producerist orientation of Lowenthal's "Idols of Production" - only the product they are selling is themselves. With this pervasive self-advertising in mind, we call these stars "Idols of Promotion."

Just as Lowenthal understood mass idolatry as an expression of the dominant economic system, we contend that the stories our heroes tell-both in self-authored bios and in popular third-person accounts - testify to larger anxieties in a precarious job economy (Beck, 1992; Giddens, 1991; Bauman, $2001,2013)$. In the face of uncertainty and against the backdrop of discourses and practices of neoliberalism, the guiding command is to orchestrate one's "life project" in earnest (Gill, 2010). With solids melted into air, responsibility for success or failure is the individual's alone-or so we come to believe. Identity has thus become something more like a task - an open-ended and unstable campaign waged on one's own. Our claim is that the eruption of self-branding rhetoric among today's idols is linked to the unsettling experience of you're-on-your-own workplace capitalism. The self-branding arts of today's idols are lessons-in-performance for making it in vertiginous times.

\section{“The Triumph of Mass Idols" in Context}

“The Triumph of Mass Idols" was initially published in the second installment of Radio Research (19421943), the collection edited by Columbia sociologist Paul Lazarsfeld and CBS research director Frank Stanton. Lowenthal's findings were twofold: First, there had been a significant increase in the quantity of biographies; and, second, there was a dramatic qualitative shift in the subject-content. To account for the change, he turned to socio-economic transformations: The production economy first, and then a consumer economy, both generated idols in their own image. Lowenthal's study included a rich analysis of the consumer-era biographies, with "consumption [as] a thread running through every aspect of these stories" (p. 519). The emphasis, he observed, was almost exclusively on idols' private lives, with an obsessive focus on personal tastes. In narrative terms, the stories portray their hero as passive and acted-upon, "a static image of a human being to whom a number of things happen, culminating in a success which seems to be none of his doing" (p. 532). Achievement in these stories, unlike the bootstrappist framing of the earlier idols, "merely happens" (p. 534), with celebrity hinging on a sequence of hardship and "breaks." Moreover, the stories supplied a diversionary service, dangling the "experience of being at one with the lofty and great in the sphere of consumption" in place of the "large confusing issues" in politics and economics (p. 548). The celebrity profiles thus offer lessons in conformist accommodation to an economic order of inert consumption. 
Lowenthal's study was reprinted in the nascent communication field's readers, and many subsequent works have adopted his tacit theory of celebrity: Mills (1956), for instance, understood emergent celebrities, or "the names that need no further identification," as a "kaleidoscope of highly distracting images" that mask the real centers of elite control (p. 92). Boorstin (1961) related prevailing social conditions to celebrity in explaining the displacement of merited fame ("heroism") to the modern, undeserved kind ("celebrity"). Two classics in the history of film-centric star studies, Morin (1961) and Dyer (1979), link the Hollywood celebrity system to capitalism and the modal American self; Dyer (1979) made the explicit claim that the only way to fully understand celebrity is at an ideological level (p. 153).

More recent contributions to fame and celebrity studies (e.g., Braudy, 1997; Driessens, 2013; Gamson, 1994; King, 1987; Langer, 1981; Marshall, 1997; Rojek, 2001; Stacey, 1994) pay at least citational homage to Lowenthal, with many of these works framing celebrity culture as an expression of larger politicaleconomic and social systems. Or, as Dyer (1986) reminds, celebrities "are both labour and the thing that labour produces" (p. 5). Other communication scholarship has, at the same time, highlighted facets of the celebrity-media-power nexus that the "mass idols" study neglected. The docile uniformity that Lowenthal, in his critique of the "Idols of Consumption," imputed to mid-century audiences has drawn justified criticism (Illouz, 2003). More broadly, the original "Idols" study treated the media landscape as more or less static, with a single medium (magazines) serving as a stable empirical backdrop. But in the decades since, media scholars have demonstrated how changing modes of delivery affect the celebrity-audience relationship. The subsequent dominance of television is a notable case in point. Langer (1981), among others, argued that TV's living-room familiarity cultivates a more intimate celebrity image; the medium underwrites a "personality" system in place of cinema's more rarefied system of stardom. The talk show genre and, later, reality programming only reinforced the small screen's earthbound brand of fame (Rojek, 2001).

By the aughts, with the "democratization of fame" pitched to the public through American Idol-type talent competitions, worship and distance had, to some extent, given way to identification and paraintimacy (Gamson, 2011). The growing prominence of "ordinary people" in the contemporary media landscape is evidence of what Turner (2009) called a "demotic turn"-one that was pivotal, but also, he cautioned, not necessarily democratic. Scholars also used reality TV to probe the changing contours of fame amid wider themes of neoliberal subjectivity (Sender, 2006; Ouellette \& Hay, 2008); the (re)presentation of ordinary life (Grindstaff, 2011); and the labor of self-production (Hearn, 2006, 2010). The rise of social media has, arguably, intensified the intimacy and personalization that Langer (1981) identified with television (Rojek, 2015). One index is the spread, from celebrities to aspirants and everyday users, is of "micro-celebrity" techniques - "a new style of online performance in which people employ webcams, video, audio, blogs, and social networking sites to 'amp up' their popularity" (Senft, 2008, p. 25). Over the last decade, scholars have utilized the micro-celebrity framework to 
examine other internet personalities and subcultures-YouTube stars, Instagram influencers, Silicon Valley status-seekers, and more (e.g., Marwick, 2013; Abidin, 2018; Khamis et al., 2017).

Traditional stardom remains unquestionably prominent, as our own social media and television-guest data confirm. But the visibility of so-called influencers, as well as the much broader adoption of microcelebrity techniques, has further blurred the already gauzy distinction between celebrity and the everyday. Traditional celebrities, moreover, occupy the same impression-management platformsInstagram, Twitter, YouTube, and Snapchat-as ordinary people and influencers (Hearn \& Schoenhoff, 2015). This partial collapse of social distance encourages identification with, and role modeling by, film stars and popular musicians. Their self-branding practices - the representations of their own career-related visibility - are directly relevant to fans and aspirants navigating their own visibility mandates (Baym, 2018; Duffy \& Wissinger, 2017).

\section{Precarity and the Branded Self}

Given that Lowenthal related cultural renown to wide-frame economic conditions, it seems crucial to briefly trace some of the profound shifts that have taken place since his writing. $\cdot$ Both consumer spending and credit debt skyrocketed in the first two decades of the postwar era (Collins, 2000); in this respect, Lowenthal's analysis was prescient. Indeed, by the mid-1950s, a full-scale consumers' republic-with its sprawling shopping centers and towering interstate billboards-took on its recognizable shape (Cohen, 2003). In the sixty years since, selling and buying have grown closer than ever to the culture's beating heart. So if mass consumption remains unflaggingly central to our economy, the explanation for the shift in celebrity profiles that we document must lie elsewhere. We suggest that widespread changes in the conditions of work are a decisive factor.

A bundle of well-documented labor-market developments-shortened job tenure, declining privatesector union ranks, de-industrialization, service-economy growth, and regulatory rollbacks-have injected more instability into the average worker's career (Neff, 2012; Ross, 2009; Sennett, 2007). The sense of go-it-alone precarity has roots in overlapping economic, political, and cultural dynamics that strengthened in the 1970s. The mid-decade oil shock, global import competition in core manufacturing sectors like cars and steel, and a slowdown in both GDP and productivity growth all served to weaken the relative job security enjoyed by American workers in the 1950s and 1960s. Trends already underway, like growing income inequality and union-membership declines, were accelerated by Carter and Reagan administration policies in the late 1970s and 1980s. Deregulation, tax cuts for business and the well-heeled, incentives for outsourcing and tax avoidance, and an unraveling social safety net into the new millennium have left the postwar social contract enfeebled. Over the same fiftyyear period the service-and information-related share of the U.S. labor market has continued to expand, populated by industries already adapted to the independent-contractor "1099" economy 
(Lane, 2013). For all its trapping of digital innovation, the so-called "gig" economy-marked by parttime, piecemeal, and freelance work -is, more likely, an intensification of existing labor-market dynamics (Morgan \& Nelligan, 2018).

One cultural response to the new insecurity, gathering momentum since the late 1990s, is an entrepreneurial imperative that calls on individuals to engage in strategic self-promotion (Duffy, 2017; Gershon, 2017; Gill, 2010; Hearn, 2008, 2010; Neff et al., 2005; Vallas \& Cummins, 2015). As a cultural ideal, self-branding has cultural antecedents that well predate the dotcom boom. The directive to stage-manage an attractive front was, for example, a prominent expression of the twentieth-century U.S. consumer culture, most notably in Dale Carnegie's 1936 bestseller How to Win Friends and Influence People (Pooley, 2010). And by the late 1990s, management guru Tom Peters was encouraging Fast Company readers to think of themselves as the "CEO of Me, Inc." (Peters, 1997). Soon thereafter, Wired magazine, books like Free Agent Nation (Pink, 2001), and advice posted across the internet celebrated precarity as "free agent" flexibility. The overarching message in these texts was to embrace the uncertainty and seize the opportunity to author one's own career (Vallas \& Cummins, 2015).

At the same time, social media sites like Facebook, LinkedIn, Twitter, and Instagram, among others, have furnished new platforms for strategic self-expression within the metrics-driven "reputation economy" (Hearn, 2010; Gandini, 2016; Marwick, 2013). Workers of all stripes are roused to build and maintain social networks as "audiences" while sharing "content" that expresses their authentic personal brand. The present study tracks this amplified culture of everyday self-promotion, as modeled by celebrities.

\section{Method}

Our project sought to map the contours of mediated idolatry in the present era, using Lowenthal's original framework, while responding to the need to reappraise symbols of "popular culture" amid a profoundly transformed media ecology. Our analysis, which included quantitative and qualitative facets, proceeded in three phases.

The first phase included data collection from two U.S.-based magazines, Time and People-periodicals drawn from a list of top-ranking magazines and selected for their large circulations and generalinterest appeal (MRI, 2017). Similar to the titles in Lowenthal's sample, Time and People bring together current events with human-interest stories offering more mainstream appeal-and thereby cultural impact - than the celebrity weeklies. A systematic sample of issues published in 2016 and 2017 were reviewed for "profile" articles - feature-length or shorter accounts that focus on the "life story" of a single individual. We first classified each of the 127 profile subjects into one of three umbrella categories, drawn from Lowenthal (p. 510): (i) Political (“Sphere of politics”); (ii) Business and 
professional ("Sphere of production"); and (iii) Entertainment ("Sphere of consumption"). Based on the initial analysis, the authors developed a series of secondary occupational categories, which were assigned to profile subjects. The text of each article was then coded qualitatively, using themes identified during the first, inductive phase of analysis; this included expressions of career "passion"; assertions of "authenticity"; claims of relatability with, and responsiveness to, audiences; references to "hard work"; and expressions of gratitude.

The second phase of the study focused on two large, U.S.-based social media platforms, Twitter and Instagram. The services were selected for their large U.S. user bases, their follower/follow network structure, and their affordance for personal broadcasting to digitally networked publics. Both platforms invite users to submit short, textual self-descriptions ("bio" is the two services' shared label), upload profile pictures ("profile photo"), and-in the case of Twitter-a second, background image ("header photo"). The top 100 individual, U.S.-based Twitter and Instagram accounts, as measured by followers, were identified (Social Blade, 2017). The rationale for the focus on the mostfollowed users is their audience-certified "celebrity" status-a "popular" anointment distinct from, but entwined with, magazines' editorial decision-making. The initial Twitter list was generated from a third-party social media analytics company, Twitter Counter. Institutional accounts and groups were removed, yielding 100 individual accounts. Similar to the first phase, the authors tracked occupational status and conducted a thematic analysis of the profile content.

We supplemented the qualitative dimensions of the study with a catalogue of guests on two of the topranking talk shows: The Ellen DeGeneres Show and Jimmy Kimmel Live. With television viewing (timeshifted or otherwise) still dominant, appearance on a daily/nighttime talk shows is, arguably, a more telling marker of celebrity status than magazine coverage. A total of 462 installments of the shows were catalogued for their guests - some of whom appeared on the same program more than oncefrom 2015 to 2016. In addition to tracking guests' occupational sphere (politics, consumption, entertainment) and narrower domain of influence, we also coded for gender identity and race/ethnicity in order to better understand who gets mythologized.

\section{Findings}

Our analysis reveals the rise of a new generation of media-hyped heroes, which we term "Idols of Promotion." These public figures, we argue, straddle the realms of production and consumption as they labor to cultivate a self-brand while reinforcing narratives of democratic success. Though the idols tend to hail from the same consumption sphere that Lowenthal reported in his 1940s sample, the narratives themselves focus on the stars' bootstrappist pluck. The 21st-century idols, in other words, blend Lowenthal's two predecessor-types in a telling manner: Movie stars and musicians, from the 
sphere of consumption, get described (and describe themselves) in production terms. The difference is that their product is themselves, and they come off as their own publicists.

Recall that Lowenthal's (1944) study reported a dramatic increase in the proportion of bios centered on consumption, with corresponding reductions in politics- and business-oriented profiles. By 1941, more than half ( 55 percent) of the magazine-anointed heroes were entertainers, up from just over a quarter (26 percent) in the earlier period (p. 510). Our sample suggests that in the decades since, the sphere of consumption has increased its share still further. Fully 92 percent of our public figures-inclusive of social media accounts, magazines profiles, and TV guests - hail from the world of consumption. Politicians account for just 5 percent while business figures are barely represented (at 1.5 percent). Though the proportions of consumption-oriented idols vary from social media to magazine profiles to TV guests, it is only in the magazine profiles that politicians (16 percent) and business leaders (5 percent) register a significant presence. The former figure, moreover, may be inflated given that our data sampling covered the 2016 U.S. Presidential campaign and its aftermath.

In terms of demographics, most (74 percent) of the public figures in our sample are white, with far fewer African Americans (18 percent) and Latinos (5 percent). East Asians (0.7 percent) and South Asians (0.8 percent) are nearly invisible, along with figures identified as mixed race (1.5 percent). There were notable differences within our sample, however: African Americans made up nearly a third (32 percent) of Twitter accounts, but only 16 percent of the magazine profiles. Latinos, by contrast, are hardly represented ( 3 percent) in the magazine stories, but make up 15 percent of the Instagram accounts. As for the gender breakdown, just over half (53 percent) of all public figures in our sample are male. The magazine subjects (64 percent) and Instagrammers (60 percent) skew female, while TV guests ( 56 percent) and Twitter accounts (60 percent) lean male. The age difference among the idols reflects the relative premium placed on youth among the spheres. Consumptionoriented figures are, on average, 40 years old. The mean age for politicians is 58 , and the few businesspeople represented are 51 years old.

In the original study, Lowenthal further classified the idols of consumption, dividing them into a series of sub-spheres. "Entertainers and sports figures" were the most plentiful, making up three-quarters (76 percent) of Lowenthal's consumption heroes. "Newspaper and radio figures" trailed at just 11 percent, with "light fiction" authors (7 percent) and product salespeople ( 5 percent) rounding out the rest. We followed Lowenthal in dividing up the consumption celebrities by profession, though with distinctive categories better oriented to the current media landscape. Over half (57\%) of the consumption-oriented figures in our sample were "screen" idols, drawn from Hollywood and television. Musicians made up a quarter (27 percent) of the profiles, while athletes registered only 6 percent. All the other categories combined-authors, artists, models, comedians, and social media influencer-made up the 10 percent remainder. There were distinct ratios by platform: Music stars 
were nearly half (49 percent) of Twitter consumption-oriented profiles, outstripping screen idols (31 percent). Media celebrities, by contrast, were nearly two-thirds (64 percent) of the TV guests-an inflated figure that could be accounted for by the longstanding convention of allotting time for TV guests to promote their latest enterprise (Langer, 1981, p. 360).

One reading of our data, set alongside the older findings, is that the half-century growth in consumption idols charted by Lowenthal has continued apace-or even accelerated. If Lowenthal registered a significant drop-off in political and business profiles, our findings show that those spheres have nearly disappeared. The triumph of mass idols that Lowenthal announced 70-odd years ago has, if anything, turned into a rout. But we suggest a different reading: the consumption-sphere orientation of today's idols registers changes in the economy, the labor market, and new technologies of and for work. Lowenthal, after all, had judged the idols of consumption lifeless symbols of leisure. Readers, he claimed, had abandoned the production worlds of work and decision-making for the "dream world" of leisure (p. 517).

Lowenthal couldn't have known that, in the decades to come, the U.S. economy's media and information sectors would crowd out-especially in employment terms - manufacturing. Put glibly, leisure itself had become the linchpin of the economy by the new millennium. Together with other changes in the labor market-shorter tenures, the growth of part-time and piecemeal work - and the more recent emergence of platforms for mediated self-expression, the sphere of "consumption" had, as it were, taken on production too. Today's celebrity biographies-many of them self-authored-are as much about providing career templates as dream-world escape. In that sense, Lowenthal's early 20th-century parables of self-made business success have, as their 21st-century counterpart, the Instagram accounts of movie and reality TV stars. The difference is not only the site where self-won success is modeled, but also the mode of making it: The relevant skills, today, are promotional. Such self-branding, we found in our qualitative analysis, was articulated through three key tropes: (1) a promise of meritocracy; (2) a spirit of cross-platform self-enterprise; and (3) an incitement to express oneself authentically. The social media and magazine profiles did not always express these themes in neatly compartmentalized fashion. We discuss these internal contradictions below.

\section{A Promise of Meritocracy}

In contrast to Lowenthal's "Idols of Consumption," portrayed as the passive beneficiaries of luck, 21stcentury success is overwhelmingly attributed to hard work, talent, or both. E-commerce entrepreneur Chieh Huang was profiled in People magazine's "My American Dream: Great Success Against the Odds." Under headers like "Humble Beginnings" and "A Drive to Achieve," Huang reflects on his work ethic: “'At any early age, I had drive...I put my mind to do something and got it done." Later, he recalls, "We worked day and night. But when you're on a mission, you keep going." While the profile of Huang -an intrepid tech tycoon-is reminiscent of Lowenthal's production archetypes, profiles of entertainers 
featured comparable narratives of hard-won success. A Time profile of DJ Khaled, for example, chronicles the music-industry figure's hardscrabble childhood, redeemed by "being taught the value of hard work." The author recounts his arduous ascent to the ranks of celebrity: There was no "overnight stardom" for Khaled. A People cover story on Steve Harvey, meanwhile, positions the entertainer at "the helm of an empire estimated to be worth $\$ 100$ million, a fortune amassed from lucrative stand-up appearances, bestselling books and movie adaptations, and multiple TV and radio gigs." Such success is a marked departure from Harvey's childhood poverty and, later, homelessness, when he was "surviving on bologna sandwiches and living out of a Ford Tempo." The message in these and other paradigmatic "rags-to-riches" accounts is that success has less to do with serendipity and more to do with elbow grease and skill.

Other magazine profiles detail dogged persistence in the face of career defeat. Actress Malin Ackerman recalls the futility of her initial forays into acting: "I didn't get a single job the first year I was [in LA] ...I was failing." A feature on supermodel Gisele Bündchen, similarly, notes how "success didn't come easy." Describing a string of forty-two rejections, she explains, "I remember some people telling me my nose was too big or my eyes were too small, that I could never be on a magazine cover." But Academy Award nominee Jessica Chastain's quoted assurance- "If you continue to be the best one in the audition, the dam is going to break" - encourages steadfast resilience despite such career roadblocks. In many of these tales, earlier accounts of plucked-from-obscurity "luck" get recast as the result of a merited state of being lucky. Former model Christie Brinkley modifies a familiar adage - “The harder I work, the luckier I feel..." and adds, "And I have worked really hard for the past 40 years!"

To be sure, not all magazine biographies constitute mediated hero-worship. Some chronicle alreadyknown figures who have committed transgressions: A profile of journalist Brian Williams details a series of deceptive news reports, while a feature on reality TV personality Josh Duggar focuses on the aftermath of his infidelity. But, more often, tales of addiction, financial trouble, or failed relationships were buffered by resonant messages of overcoming adversity. As a teen, musician Armando Christian Pérez - better known as Pitbull-spent his days "hustling and dealing drugs in the sweaty streets of Miami," before his mother kicked him out. It was a self-described "w[a]ke-up" call, which propelled him to turn to music. "In this country," he told People, "you have the opportunity to become who you want to become and do what you want to do with your life." Country singer Brandy Clark, meanwhile, "grew up in a trailer" and "early on the family didn't have a TV." In other cases, personal struggle becomes fodder for creative self-expression. After singer Ryan Speedo Green found himself in juvenile detention at just twelve, he realized he could "channel that rage into other things."

Structural inequalities, when acknowledged, often take a backseat to personal adversities. Celebrated entrepreneur Joy Mangano, for instance, nods toward the male-dominated culture of 
entrepreneurship: "As a single-mom female inventor," she recalls in People, "there was no path, so really I don't think people took me seriously for a really long time." Similarly, a magazine feature on Oscar-winner Octavia Spencer notes how "she worked long and hard for her own stellar success" and confronted myriad "glass ceilings" as a woman of color. As she explains, "You have to see the sky as the limit - otherwise you'll never get off the ground." Despite this brief allusion, the article underplays the realities of occupational segregation, focusing instead on the challenges Spencer experienced after losing her mother at age eighteen.

Our sample included a handful of magazine profiles that betrayed their Horatio Alger storylines with details of their subjects' privilege. A Time feature on YouTube CEO Susan Wojcicki, for instance, mentions that her father was a Stanford physicist, and that she attended Harvard. A People article on Georgina Bloomberg (Michael Bloomberg's daughter) retained the self-made storyline despite the equestrian Olympic aspirant's family fortune. "I have no natural talent; I had to learn to work for it," reads a pull-quote; "I'm very proud of the fact that I've still accomplished what I have." The takeaway, here, is that today's idols are framed as the authors of their own destiny, even when evidence from the articles suggests a more complicated reality.

In a sense, this meritocratic lens represents a return to Lowenthal's early 20th-century "Idols of Production." The difference is that the profiles celebrate the self-made success of entertainers far more often than the business figures and politicians who dominated Lowenthal's sample. Invocations of meritocracy were apparent in the self-authored social media bios, too, although less frequently than some of the other themes that we detail below. Actor-comedian Kevin Hart's Twitter bio reads, "My name is Kevin Hart and I WORK HARD!!! That pretty much sums me up!!! Everybody Wants To Be Famous But Nobody Wants To Do The Work." Meanwhile, on Instagram, YouTube comedian and actress Liza Koshy's profile reads: "God 1st. Little brown girl with big dreams," before offering an inventory of her other social media profiles-Twitter, Snapchat, Google, and YouTube-a nod toward crosspromotional prowess.

\section{A Spirit of Entrepreneurship}

The most consistent feature of the Twitter and Instagram bios in our sample is unabashed selfpromotion, with figures casting themselves as cross-media entrepreneurs. Nearly half of the social media accounts analyzed (ninety-one of the 189 that included textual content) contained a selfpromotional reference. Musician Selena Gomez hawked her album: “\#REVIVAL OUT NOW”; reality star Kylie Jenner directed followers to her Snapchat account and cosmetics line; actress-comedian Mindy Kaling publicized that "February 14th, The Mindy Project returns to @Hulu! Why Not Me? is my second book"; and internet personality Cameron Dallas prodded his followers to "Watch Chasing Cameron on Netflix!" Even the occasional nod to biography (e.g., Stephen Curry's "Believer. Husband to @ayeshacurry, father to Riley and Ryan, son, brother. Golden State Warriors guard. Davidson 
Wildcat") or humor (e.g., Ellen DeGeneres's "My tweets are real, and they're spectacular") is eclipsed by self-marketing. A prime example of such digitally networked self-aggrandizement is Kim Kardashian West's bio, which is nothing but a link to the KIM KARDASHIAN WEST / OFFICIAL APP. Paris Hilton, meanwhile, uses her Twitter bio to market her new fragrance. Other social media biographies redirect visitors to agents and talent mangers; Scott Disick's Instagram profile merely lists a contact for bookings inquiries. The stars' self-descriptive choices - their tendency to cede their biographical real estate to their latest business venture - signal that publicity and entrepreneurial craft anchor these idols' self-presentations.

In a handful of self-authored bios, the "entrepreneur" designator is expressly deployed-despite the fact that these social media favorites hail from, in Lowenthal's terms, the "consumption" sphere. Demi Lovato, for example, describes herself as a "Singer, Songwriter, Actress, Entrepreneur, Philanthropist," while Pitbull's profile reads: "Mr. Worldwide. Musician. Entertainer. Entrepreneur." These examples index the more pervasive trend of burnishing oneself as a dynamic media hyphenate. With Kobe Bryant as the self-appointed "CEO Kobe Inc. Publisher. Investor. Producer” and Ashley Tisdale describing her self as "Actress, producer, singer, professional illuminator," today's heroes claim industry-spanning acumen - celebrating the kinds of labile labor (Morgan \& Nelligan, 2018) and do-itall multi-skilling (Gill, 2010; Duffy \& Wissinger, 2017) that animate cultural workers.

Discussions of enterprising, cross-promotional finesse also appeared in our sample of magazine profiles, although to a lesser degree. Jennifer Lopez remains "disciplined as always about her career," which now spans "American Idol judging, producing the ABC Family sitcom The Fosters, writing a bestselling memoir, singing, dancing and acting." A People cover feature on Reese Witherspoon, meanwhile, places the actress in the company of fellow celebrity-entrepreneurs:

As Witherspoon has figured out, the groomed, likable persona that generates fame in Hollywood can also be converted into cash. Now she's among a growing set of stars - ranging from their late 20s to early 40s and including Gwyneth Paltrow, Jessica Alba and Blake Lively-peddling the ephemera of their domestic bliss.

A profile of Christie Brinkley, likewise, lingers on the model's successful conversion of cover girl fame to lucrative business ventures: "Now 62, Brinkley is still modeling and has parlayed her ageless allAmerican sex appeal into a lifestyle empire worth an estimated $\$ 80$ million... Next up, Brinkley has a new line of organic prosecco, Bellissima, launching this summer." Here, the magazine journalists portray their subjects as savvy business-people, who deploy their image-aware marketing skills to attain still-greater (financial) success. They are, in other words, human brands-well-known individuals who have hitched their star power to product marketing (Thompson, 2006). 
Few of the idols exhibited modesty in discussing their entrepreneurial visions. Teresa Giudice of The Real Housewives franchise credited prison with the sort of self-discovery that could be channeled into business success. She recalled, "I want to make $\$ 40$ million this year. I hope that happens -for real, I made a vision board. I want to come out with my own yoga DVD tape, my own yoga line." Tellingly, the feature serves as a pseudo-ad for her "new tell-all," which was co-written by a People staffer. A Time feature on Nicky Minaj, likewise, explained how she was "strategic about the business end of her empire" from the get-go. She explained: "I always wanted to know the ins and outs of the business. I hate when artists don't know what the hell is going on in their career." As these articles make clear, contemporary idols made few efforts to temper their professional aspirations; creativity and business seamlessly commingle. Though the commercial side of work was once a foil to artistic license, business acumen is now "integral and actively incorporated into the artistic identity" (McRobbie, 2002, p. 520). As Morgan and Nelligan (2018) have observed, the "creative economy is in part a discursive trick concerned with promoting flexibility and the mobility of labour" (p. 6).

\section{Authenticity}

A third theme across the magazine and social media bios is authenticity. Readers and followers are told by reporters, and by the stars themselves, that the self these figures display to the world is the genuine article. YouTube personality Tyler Oakley tells Time, "Authenticity is more important than attempting to seem relatable. I would rather be me than something that's more retweetable." While the comment is unsurprising from a social media entertainer-given these communities' constant "testing" of authenticity claims in what Cunningham and Craig (2017, p. 74) describe as a "a call-andresponse rhetorical field" - traditional celebrities made similar statements. As broadcast journalist Tamron Hall tells People: “The biggest compliment is when fans tell me, 'You're so real." The story follows up with an endorsement from a showrunner: "She's fly, she's beautiful and so whip smart, but it's her authenticity that comes across immediately." The overriding message, in these and many of the other magazine stories in our sample, is that the celebrity-subjects' performed self aligns with who they are really are. On Twitter and Instagram, the same claim is made, frequently paired with a direct exhortation to fans.

Model Cara Delevinge's Twitter bio accents expressive authenticity with a call to "EMRACE YOUR WEIRDNESS!." and continues, "I am unprofessionally professional human being." She closes with a second, all-caps entreaty: "STOP LABELING! START LIVING." Basketball player Kevin Durant, on his Twitter profile, offers a pithy descriptor: “I’M ME, I DO ME, AND I CHILL." In these cases, and many others, the celebrities use their social media accounts to affirm their honest self-display.

Far more common than overt testimonials, in both the magazine articles and the social media profiles, are nods to the quotidian, which seem to assure readers that profile-subjects are a lot like them. Of course, the notion that stars are just like us has been a recurrent theme in tabloids, gossip magazines 
and, since the mid-aughts, blogs, all of which offer a fleeting glimpse into celebrities' off-screen, unvarnished, purportedly “real” lives (Langer, 1981). Jennifer Lopez, in a typical passage, was described as a "surprisingly down-to-earth super-star and hands-on mother." Another describes how actress Hailee Steinfeld is, "in some ways," like other 18-year-olds: "She worships Beyoncé, carts around her iPhone charger, frets about boys and obsesses about her future." At other times, the ordinariness point is delivered through the profile subjects' own words. Hilary Duff, for example, describes her life as "more normal than people think" - despite growing up in front of the cameras as Disney's fictional Lizzie McGuire.

Appeals to relatability-including autobiographical self-effacement-appeared in the social media profiles, too, though less frequently. On Twitter, Ryan Seacrest describes himself as a "proud son, brother, friend, my lab Georgia's dad, broadcaster, producer, passion for music, food, travel, art \& bringing smiles to kids in hospitals across US," while actor/entertainer Neil Patrick Harris notes that he "dig[s] variety acts, Pixar, puppets, prestidigitation, immersive theatre, game shows, theme parks, my family and great meals. Not necessarily in that order." In both instances, the media-hyped star downplays celebrity status by emphasizing his off-screen persona. The relatively few top-100 social media accounts tied to politics follow this script. Hillary Clinton begins her Twitter bio with "Wife, mom, grandma," and includes "hair icon" and "pantsuit aficionado" within a long list of government positions. Some of the social media bios use conversational, second-person address-“designed informality" in Horton and Wohl's (1956) term (p. 216). Instagram influencer Jen Selter's profile is one word: "Hi!" Tom Hanks plays down his acting talent-“I'm that actor in some of the movies you liked and some you didn't"-before admitting he's often out of shape: "Hey, you gotta live, you know?" Here, Hanks projects himself as an unpretentious everyman.

\section{Authentic Self-Promotion}

In a subset of the magazine profiles and social-media biographies, we found that cross-promotion, authenticity, and perseverance all appear, in sometimes-jarring juxtaposition. These contradictions challenge the tidiness of our three-trope analysis, and offer support for Baym's (2018) claim that musicians' expressions of authenticity "can bring life-enriching consequences" while also rendering them vulnerable (p. 173). The contradictions in our sample are revealing in their own right, as expressions of underlying conflicts among cultural ideals. The profile of DJ Khaled, for instance, meditates on his incessant drive and message discipline - which, the article suggests, reflect Khaled's actual self. "Even before Snapchat, you go back into my career from Day One or interview people that knew me for 25 years," Time quotes the music-industry figure, "they're going to tell you I've been DJ Khaled my whole life." As the reporter admits, it is "tempting to dismiss Khaled's relentless optimism as calculated performance," but he "seems to believe in his own teaching." Self-promotion and hard work, the profile suggests, are and always have been at the core of DJ Khaled's identity. 
The blend of authentic living and self-promotion is, in some magazine articles and social profiles, boldy embraced. People's profile of Gwen Stefani manages to sandwich a business venture mention within the musician's endorsement of purposeful living:

'I've been really working hard on my spiritual exercising, and when you do that, I think you find suddenly you're seeing in color,' says Stefani, who is executive producing Nickelodeon's new kids' show Kuu Kuu Harajuku (airing Saturdays at 9a.m.). 'Everything has more meaning and more feeling and more purpose. I'm the happiest I've ever been'.

Beneath the quote is a graphic touting “Gwen's Exclusive Collection for People Shop!" Even in this example, the discordant note - the mix of authenticity with commerce-is partially resolved by the story's narrative arc: Stefani had hit a rough patch in her career, which she has corrected through her recent, Zen-like re-centering. Jessica Alba's Twitter bio drops her consumer-goods business - already branded in ethical terms - into a list of self-deprecating traits: "Mom of 2, Founder of The Honest Company, amateur chef, terrible speller, loyal friend, hilarious at times... I play make believe for a living."

Sometimes, especially in the compact format of the social-media bio, authentic self-expression and the art of promotion are more awkwardly commingled. Actress Bella Thorne writes on Instagram that "Life is art. There is no right or wrong way to create art." The bio shifts to a product announcement: "Famous in Love now on Freeform" followed by a hyperlink. There is, in Thorne's case as well as many others, an abrupt transition from earnest soul-baring to selling. In her Instagram bio, actress Lucy Hale describes herself as a "Champion napper, 5'2", loves ramen," with an immediate pivot to product: “--My phone case capsule available here www.casetify.com/lucy-hale." The tension-filled but pervasive cocktail of calculation and authenticity is found in many other cultural spheres too-from reality television and advertising (e.g., Banet-Weiser, 2012; Grindstaff, 2015) to internet entrepreneurs and social media-enabled creative workers (e.g., Baym, 2018; Cunningham \& Craig, 2017; Duffy, 2017; Marwick, 2013). That message offers a paradoxical injunction: to use honest self-expression to get ahead (Pooley, 2010). In a labor economy that asks workers to repeatedly sell themselves, the adviceimplicitly modeled in our sample-makes some internal sense: cultivating a true-to-self persona is a form of affective value-creation that - in an employment market characterized by siloed precaritycan lead to offers, promotion, and other forms of individual gain (Hearn, 2010).

\section{Conclusion}

Our analysis of 21st century mediated biographies reveals a melding of key features of Lowenthal's idols of production and consumption: self-made success, like the former, but achieved in the entertainment arena, as with the latter. But unlike Lowenthal's second generation-the mid-century 
"consumption" idols - the new heroes narrate their own mastery of the publicity arts, inviting fans and followers to emulate their example. As befits the image-saturated realm of the culture industries, the emphasis - in these recent biographies - is on self-branding know-how. The individual-account format on Instagram and Twitter reinforces the message that the stars are not merely objects of mass consumption, but also author-producers of their own careers. They are, in other words, Idols of Promotion.

And much like their antecedents, these cultural exemplars reflect-and double-back uponprevailing economic conditions. The new Idols of Promotion, we contend, index larger anxieties about the individualization of work at a moment when risk gets shifted to workers as benefits get stripped away (e.g., Beck, 2001; Neff et al., 2005; McRobbie, 2002). These idols, in other words, speak to the experience of anxious self-making that Beck (1992), Giddens (1991), and (with special acuity) Bauman (2001, 2013) articulate as a distinctive quality of "late" or "high" or "liquid" modernity. The latemodern reflexive self enjoyed a kind of terrifying freedom, they argue-intoxicated with hope but frantic at the prospect of failures. Many of us experience unpredictable and short-term labor markets as stage-like platforms, with auditions that never end. Hallowed-out state and community support structures, especially in the U.S., mean that one "bad" performance, for all but the most privileged, is potentially devastating; and throughout, "life is a pitch" (Gill, 2010). The prism of self-responsibility, moreover, means that society's "losers" bring on their own failure. If they

stay unemployed, it is because they failed to learn the skills of gaining an interview, or because they did not try hard enough to find a job or because they are, purely and simply, work-shy; if they are not sure about their career prospects and agonize about their future, it is because they are not good enough at winning friends and influencing people and failed to learn and master, as they should have done, the arts of self-expression and impressing the other. (Bauman, 2001, p. 47)

All this roving, anxious precarity gets channeled into compulsory self-improvement. Swimming ahead, or merely treading water, requires an entrepreneurial subjectivity: You are your own product, and its salesman too (cf Fromm, 1940).

One lesson for communication scholarship, inherited from Lowenthal and echoed here, is that mediated phenomena like celebrity are inseparable from the prevalent social and economic conditions. The point is not base-superstructure reflectionism; the suggestion, instead, is to attend to the mutual entanglement of the storytelling industries with broad-scale socio-economic trends. The concentrated attention that celebrity represents, in other words, is shaped by, and contributes back to, the structures that govern everyday life. Increasingly, this entails data-driven indexes of visibility, which prod individuals to trade in symbols and attention - the currency of the social media era. 
The stories of self-made success - the celebrations of promotional pluck-are parables for success amid the sprawling market of independent and piecemeal employment. They offer, in other words, lessons in self-branding. In that respect, the Idols of Promotion speak to (and strengthen) the call to curate a personal brand designed to render oneself ever-employable within a precarious labor economy. The new idols are models for the average person, who is increasingly called on to manage risk through self-promotion. The reality of success is, of course, far more complex than the skillful self-branding modeled by an aphoristic social media bio or magazine profile. The experience of handsomely paid celebrities, to the same point, hardly resembles the plight of the typical worker. The struggle to stay famous is qualitatively different from the struggle to earn a living wage. But that gap is exactly what the Idols of Promotion-or their representations-help to obscure. In both the media industries and wider neoliberal economy, structural inequalities endure, barriers to entry remain staggeringly high, and meritocracy is - as many have shown - an enduring myth. Despite the unforgiving reality, this is the message to the new precariat: You better identify your distinctive strengths, engage in brazen self-promotion, and spearhead "personal visibility" campaigns. Or else.

The Idols of Promotion concept should prove useful to a range of communication research subfields. The label, like its Lowenthal-designated precursors, places celebrity in historical and sociological relief. One takeaway is that the study of celebrity, social media platforms, and self-branding culture can be profitably joined with one another, and with sociological theory-which all too often neglects media developments. The Idols of Promotion register, in all their concentrated attention, the miasmic spread of promotional culture (Wernick, 1992; Hearn, 2008) across the once-segregated domains of work and leisure. Our findings suggest that the study of celebrity and popular culture, going forward, should attend to the sociology of work and the incessant demand for self-branding practices. The partial platformization of celebrity engagement - the parasocial boost to fan interaction-means that everyday self-performance is entangled in a shared set of post-and-story conventions. For everyone involved - and not just the Idols of Promotion - the identities we project are both personal and employable.

\section{References}

Abidin, C. (2018). Internet celebrity: Understanding fame online. Bingley, UK: Emerald Publishing.

Banet-Weiser, S. (2012). Authentic ${ }^{\mathrm{TM}}$ : The politics of ambivalence in a brand culture. New York: New York University Press.

Bauman, Z. (2001). Consuming life. Journal of Consumer Culture, 1(1), 9-29. 
Bauman, Z. (2013). Liquid times: Living in an age of uncertainty. Cambridge: Polity.

Baym, N. K. (2018). Playing to the crowd: Musicians, audiences, and the intimate work of connection. New York: NYU Press.

Beck, U. (1992). Risk society: Towards a new modernity. London, UK: Sage.

Beck, U. (2001). Living your own life in a runaway world: Individualisation, globalisation and politics. In W. Utton \& A. Giddens (Eds.), On the edge: Living with global capitalism (pp. 164-174). London: Vintage.

Boorstin, D. J. (1961). The image: A guide to pseudo-events in America. New York: Harper \& Row.

Braudy, L. (1986). The frenzy of renown: Fame and its history. Oxford: Oxford University Press.

Cohen, L. (2003). A consumers' republic: The politics of mass consumption in postwar America. New York: Knopf.

Collins, R. M. (2000). More: The politics of economic growth in postwar America. New York: Oxford University Press.

Cunningham, S., \& Craig, D. (2017). Being 'really real' on YouTube: Authenticity, community and brand culture in social media entertainment. Media International Australia, 164(1), 71-81.

Driessens, O. (2013). The celebritization of society and culture: Understanding the structural dynamics of celebrity culture. International Journal of Cultural Studies, 16(6), 641-657.

Duffy, B. E. (2017). (Not) getting paid to do what you love: Gender, social media, and aspirational work. New Haven, CT: Yale University Press.

Duffy, B. E., \& Wissinger, E. (2017). Mythologies of creative work in the social media Age: Fun, free, and "just being me". International Journal of Communication, 11.

Dyer, R. (1979). The stars. London: British Film Institute.

Dyer, R. (1986). Heavenly bodies: Film stars and society. New York: St. Martin's Press.

Fromm, E. (1941). Escape from freedom. New York: Farrar \& Rinehart.

Gamson, J. (1994). Claims to fame: Celebrity in contemporary America. Berkeley, CA: University of California Press. 
Gamson, J. (2011). The unwatched life is not worth living: The elevation of the ordinary in celebrity culture. PMLA, 126(4), 1061-1069. doi:10.1632/pmla.2011.126.4.1061

Gandini, A. (2016). Digital work: Self-branding and social capital in the freelance knowledge economy. Marketing Theory, 16(1), 123-141.

Gershon, I. (2017). Down and out in the new economy: How people find (or don't find) work today. Chicago: University of Chicago Press.

Giddens, A. (1991). Modernity and self-identity: Self and society in the late modern age. Stanford, CA: Stanford University Press.

Gill, R. (2010). Life is a pitch: Managing the self in new media work. In M. Deuze (Ed.), Managing media work (pp. 249-262). London: Sage Publications.

Gill, R., \& Kanai, A. (2018). Mediating neoliberal capitalism: Affect, subjectivity and inequality. Journal of Communication, 68(2), 318-326.

Grindstaff, L. (2010). Just be yourself - only more so: Ordinary celebrity in the era of self-service television. In M. M. Kraidy \& K. Sender (Eds.), The politics of reality television: Global perspectives (pp. 44-57). New York: Routledge.

Hearn, A. (2006). John, a 20-year-old Boston native with a great sense of humour: On the spectacularization of the self and the incorporation of identity in the age of reality television. International Journal of Media \& Cultural Politics, 2(2), 131-147.

Hearn, A. (2008). Meat, mask, burden: Probing the contours of the branded self. Journal of Consumer Culture, 8, 197-217.

Hearn, A. (2010). Structuring feeling: Web 2.0, online ranking and rating, and the digital 'reputation' economy. ephemera, 10(3/4), 421-438.

Hearn, A., \& Schoenhoff, S. (2015). From celebrity to influencer: Tracing the diffusion of celebrity value across the data stream. In P. D. Marshall \& S. Redmond (Eds.), A companion to celebrity (pp. 194212). New York: John Wiley \& Sons.

Horton, D., \& Wohl, R. (1956). Mass communication and para-social interaction: Observations on intimacy at a distance. Psychiatry, 19(3), 215-229.

Illouz, E. (2003). Redeeming consumption: On Lowenthal's “The Triumph of the Mass Idols." In E. Katz, J. D. Peters, T. Liebes, \& A. Orloff (Eds.), Canonic texts in media research (pp. 90-103). Cambridge: Polity Press. 
Khamis, S., Ang, L., \& Welling, R. (2017). Self-branding, 'micro-celebrity' and the rise of social media influencers. Celebrity Studies, 8(2), 191-208.

King, B. (1987). The star and the commodity: Notes towards a performance theory of stardom. Cultural Studies, 1(2), 145-161.

Lane, C. M. (2011). A company of one: Insecurity, independence, and the new world of white-collar unemployment. Ithaca, NY: Cornell University Press.

Langer, J. (1981). Television's 'personality system.' Media, Culture \& Society, 3(4), 351-365.

Lowenthal, L. (1944). Biographies in popular magazines. In P. F. Lazarsfeld \& F. Stanton (Eds.), Radio research, 1942-43 (pp. 507-548). New York: Duell, Sloan, and Pearce.

Marshall, P. D. (1997). Celebrity and power: Fame in contemporary culture. Minneapolis: University of Minnesota Press

Marwick, A. E. (2013). Status update: Celebrity, publicity, and branding in the social media age. New Haven, CT: Yale University Press.

McRobbie, A. (2002). Clubs to companies: Notes on the decline of political culture in speeded up creative worlds. Cultural Studies, 16(4), 516-531.

Mills, C. W. (1956). The power elite. New York: Oxford University Press.

Morgan, G., \& Nelligan, P. (2018). The creativity hoax: Precarious work in the gig economy. New York: Anthem Press.

Morin, E. (1961). The stars. New York: Grove Press.

Neff, G. (2012) Venture labor: Work and the burden of risk in innovative industries. Cambridge, MA: MIT Press.

Neff, G., Wissinger, E., \& Zukin, S. (2005). Entrepreneurial labor among cultural producers: “Cool” jobs in "hot" industries. Social Semiotics, 15(3), 307-334.

Ouellette, L., \& Hay, J. (2008). Makeover television, governmentality and the good citizen. Continuum, $22(4), 471-484$.

Peters, T. (1997, August 31). The brand called you. Fast Company. Retrieved from http://www.fastcompany.com/28905/brand-called-you 
Pink, D. H. (2001). Free agent nation: How America's new independent workers are transforming the way we live. New York: Warner Books.

Pooley, J. (2010). The consuming self: From flappers to Facebook. In M. Aronczyk \& D. Powers (Eds.), Blowing up the brand (pp. 71-89). New York: Peter Lang.

Pooley, J., \& Katz, E. (2008). Further notes on why American sociology abandoned mass communication research. Journal of Communication, 58(4), 767-786.

Rojek, C. (2001). Celebrity. London: Reaktion Books.

Rojek, C. (2015). Presumed intimacy: Parasocial interaction in media, society and celebrity culture. John Wiley \& Sons.

Ross, A. (2009). Nice work if you can get it: Life and labor in precarious times. New York: New York University Press.

Sender, K. (2006). Queens for a day: Queer Eye for the Straight Guy and the neoliberal project. Critical Studies in Media Communication, 23(2), 131-151.

Senft, T. M. (2008). Camgirls: Celebrity and community in the age of social networks. New York: Peter Lang.

Sennett, R. (2007). The culture of the new capitalism. New Haven: Yale University Press.

Social Blade. (2017). Top 100 Instagram profiles. Retrieved from

https://socialblade.com/instagram/top/100/followers

Stacey, J. (1994). Star gazing. New York: Routledge.

Turner, G. (2009). Ordinary people and the media: The demotic turn. London: Sage Publications.

Twitter Counter. (2017). Twitter Top 100 most followers in United States. Retrieved from http://twittercounter.com/pages/100/unitedstates

Thomson, M. (2006). Human brands: Investigating antecedents to consumers' stronger attachments to celebrities. Journal of Marketing, 70(3), 104-119.

Vallas, S. P., \& Cummins, E. R. (2015). Personal branding and identity norms in the popular business press: Enterprise culture in an age of precarity. Organization Studies, 36(3), 293-319.

Weiss, G. (2017, May 24). The most desired career among young people is 'YouTuber' (study). Tubefilter. Retrieved from http://www.tubefilter.com/2017/05/24/most-desired-career-young-people-your 
Wernick, A. (1992). Promotional culture. Thousand Oaks, CA: Sage Publications.

\section{REPRINT}

"Idols of Promotion: The Triumph of Self-Branding in an Age of Precarity" (Brooke Erin Duffy and Jefferson Pooley, MediArXiv, March 30, 2019, the authors' final manuscript of "Idols of Promotion: The Triumph of Self-Branding in an Age of Precarity," Journal of Communication 69, no. 1 (2019), doi: $\underline{10.1093 / \text { joc/jgy063) }}$

OPENLY LICENSED

\section{Footnotes}

1. A noteworthy exception is Driessens (2013), who questioned whether the spread of celebrity into politics, academia, business, and more industrial contexts might signal a new phase where "idols of production have also become idols of consumption" (p. 647).

2. The account here is limited by space, and focused on the United States, given our data and Lowenthal's original study. 